\title{
EXPLORING SOCIO-SPATIAL ASPECTS OF TRADITIONAL SOUQS: The Case of Souq Mutrah, Oman
}

\author{
Ahood Al-Maimani \\ MUPD Post Graduate Student, \\ Department of Architecture and Urban Planning, \\ Qatar University \\ ahood.a.almaimani@gmail.com
}

\author{
Ashraf M. Salama \\ Professor of Architecture, \\ Department of Architecture and Urban Planning, \\ Qatar University \\ asalama@qu.edu.qa \\ Fodil Fadli \\ Assistant Professor of Architecture, \\ Department of Architecture and Urban Planning, \\ Qatar University \\ f.fadli@qu.edu.qa
}

\begin{abstract}
Traditional souqs in the Arabian Peninsula continue to be major focal points of trade, commerce, exchange, entertainment and social interaction. Souq Mutrah, in Muscat, Sultanate of Oman is one of these important regional souqs. This paper develops an experiential walkthrough assessment of three selected urban spaces - market places within Souq Mutrah by examining their spatial and socio-cultural aspects while implementing direct systematic observation and behavioral mapping procedure. The findings contribute to an in-depth understanding of the qualities of the three spaces and the resulting use, activities, and behavior representative of the inhabitants' spatial experience in those spaces. Assessment results reveal important outcomes that include that safety and secuirity is the significant missing factor in Souq Mutrah spaces, which if provided, can attract more users while supporting their needs.
\end{abstract}

Keywords: traditional souqs; Souq Mutrah; walkthrough assessment; behavioral mapping.

\section{INTRODUCTION}

Market places are important centers of trade, commerce, exchange, entertainment and social interaction that have existed since ancient times in various forms starting with the agora in Ancient Greece to the modern globalized shopping malls. Traditional market places in the Arabian Peninsula, known as souqs, were focal points for the community. They usually included a wide variety of uses from; shops, mosques, madrasas (religious schools), hamams (public baths), offices, and other communal institutions. They helped enhance civic communication and socialization. Souqs can be classified according to their duration into two separate types: seasonal souqs and permanent souqs. Many seasonal souqs went into decline and disappeared, while others still continue or developed into permanent ones. Souq Mutrah is one of these permanent souqs.

Souq Mutrah is strategically located in the heart of the old city, covering an area of approximately 51,200 $\mathrm{m}^{2}$ (measured using Google Earth Pro. 2013). The souq stretches deep within the integrated urban fabric (Figure 1.). To the north, the souq's gate faces Al-Bahri Road and the Gulf of Oman. To the south, it ends up with two gates facing Mutrah High Street. Mutrah State is rich with high-rise mountains that reach up to $200 \mathrm{~m}$ above sea level. They limit development, 
and during heavy rains fill the souq's maze of pathways with rainwater that head north into the sea. This cause as all the shops to be 4 to 5 steps higher than pathways. In Mutrah State, the number of expatriates increased by $5.47 \%$ from 97,020 in 2003 to 102,637 in 2010, while the number of Omanis decreased by 19\% from 56,506 in 2003 to 47,487 in 2010 (Oman Census, 2010).

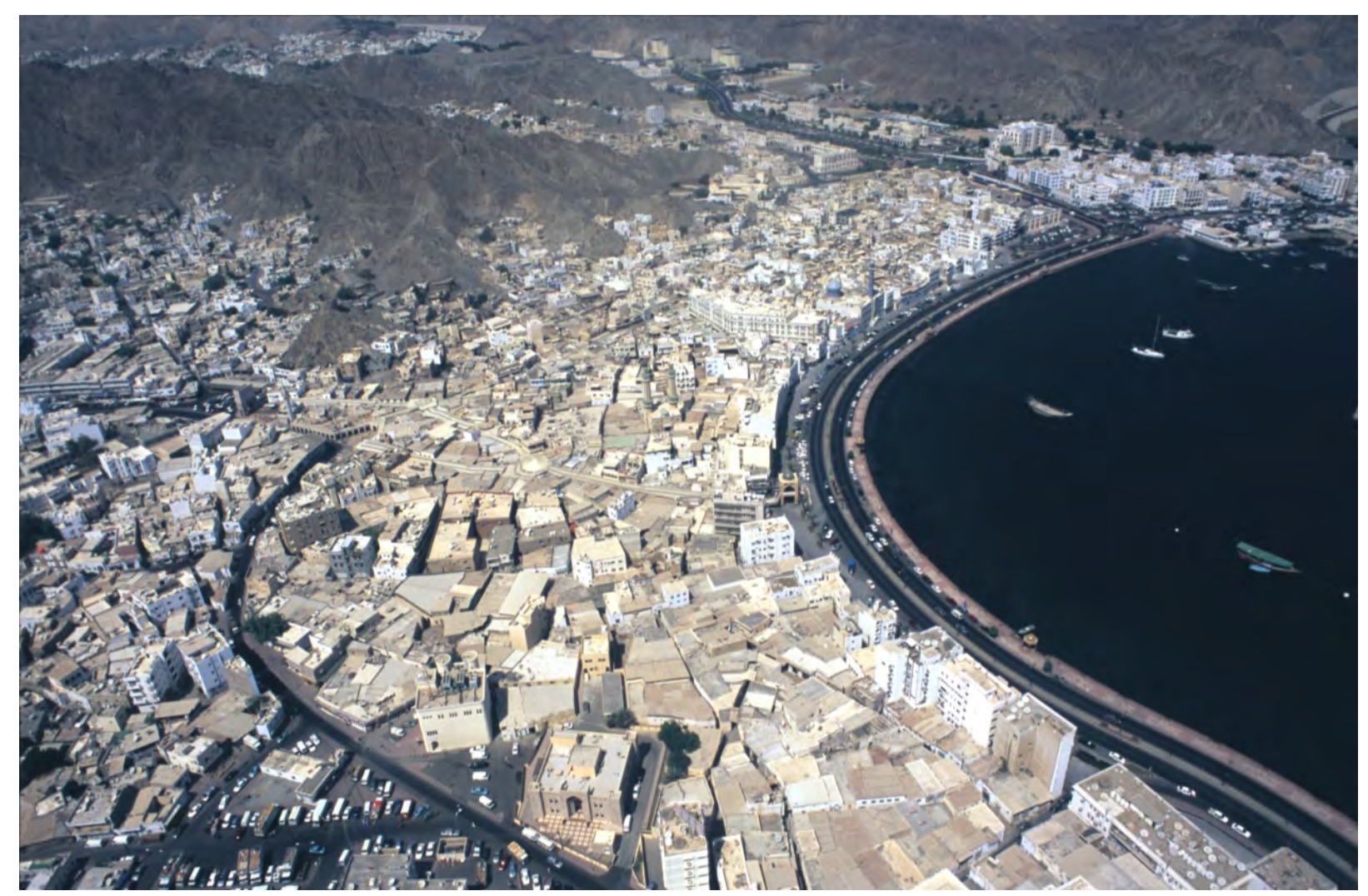

Figure 1: Bird view of Mutrah district; showing also Souq Mutrah main spine

(Source: Muscat Municipality, 2005).

Throughout the history, the area of Mutrah went through different phases of formation and growth being impacted by various indigenous tribes as well as foreign powers such as; the Portuguese in the $16^{\text {th }}$ century and the British in the $19^{\text {th }}$ and $20^{\text {th }}$ century. Until July 23,1970 when Qaboos bin Said, son of the Sultan took over as ruler. Since then, Muscat, the capital has experienced rapid infrastructural development that has led to the growth of a vibrant economy and a multi-ethnic society. Due to the concentration on developing the country, the old parts of the city including Souq Mutrah fell into gloominess. However, this was faced by responses from the local authorities throughout the years to enhance the deteriorate conditions.

During the 1990's the souq faced several issues especially regarding; safety and security. The souq suffered from exposed electrical cables, flammable roofing materials, no water hydrants, and increasing theft and looting. As a response authorities held many meetings to provide solutions, however decisions were delayed due to high estimated costs and limited budget. Later, in 2001 more attention was given to the architectural, aesthetical, and urban values of the souq. But again, decisions were delayed and action only happened in 2004-2005 in Souq Mutrah Development Project. It replaced the roofing with durable safer materials, provided water hydrants, reshaped parts of the souq, defined three major entrances, and created urban spaces. Some of these spaces were plazas open to the sky at the main entrances, and others were enclosed within the souq's urban fabric as major meeting nodes.

Availability of attractive, accessible urban spaces is important to maintain a liveable urban environment, for the inhabitants of cities and urban areas. However, this importance is sometimes 
ignored or oversimplified when authorities make decisions about land-use or when discussing the qualities of the built form. (Salama, Khalfani, and Al-Maimani, 2013). Referring to the traditional role of souqs, urban spaces should play a major role in supporting this role. In the case of Souq Mutrah, the way in which these urban spaces and plazas, shaped by the development of 20042005 , have been used and altered by its inhabitants is questioned. This is investigated through a mixed research methodology that aims to provide an understanding of socio-spatial aspects of urban spaces-market places within Souq Mutrah. Therefore, the study develops and implements tools exemplified by a self-guided walking tour and behavioral mapping procedures.

\section{METHDOLOGY}

The methodology involves wall-through assessment, and behavioral mapping procedures for three key urban spaces-market places within Souq Mutrah. A brief description of the qualities of these spaces is outlined in Table 1.

The criteria for selecting the three spaces involved the following aspects:

- The variety and type of spaces where spaces 1 and 3 are open-air exposed spaces while space 2 is a covered and enclosed space.

- The geographical location with the souq from the north end, to the center, to the south end (Figure 5).

- The variety and type of users and the nature of interaction where each spaces enjoys different type of users and spatial layout.

- Each of the three spaces has experienced different level and type of physical changes and developments, which have resulted in changes in socio-spatial and soci-economic practices.

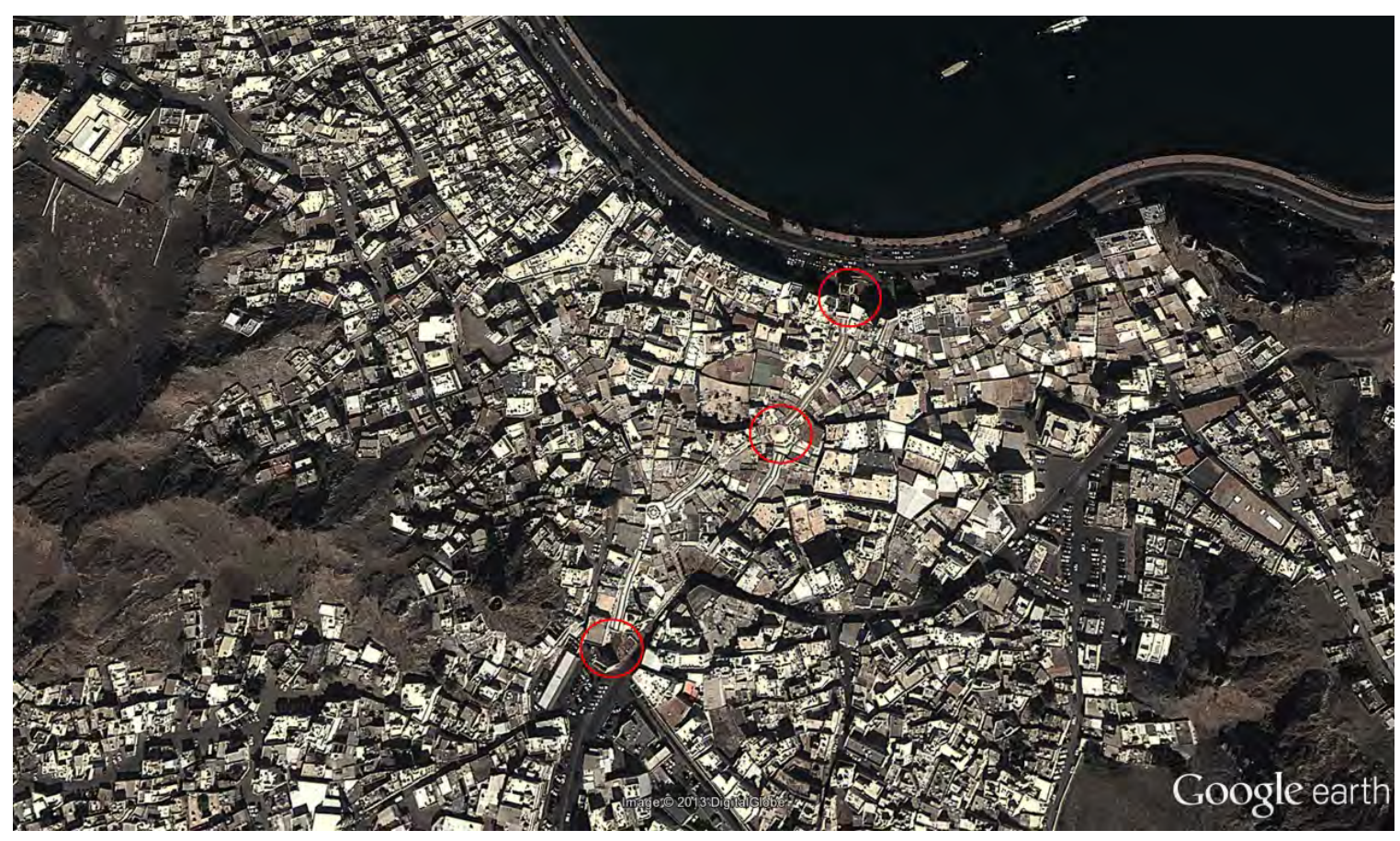

Figure 2: Map showing the three selected spaces from North to South

(Source: Google Earth, 2013). 
Table 1. Three selected studied spaces within Souq Mutrah (Source: Authors, 2013).

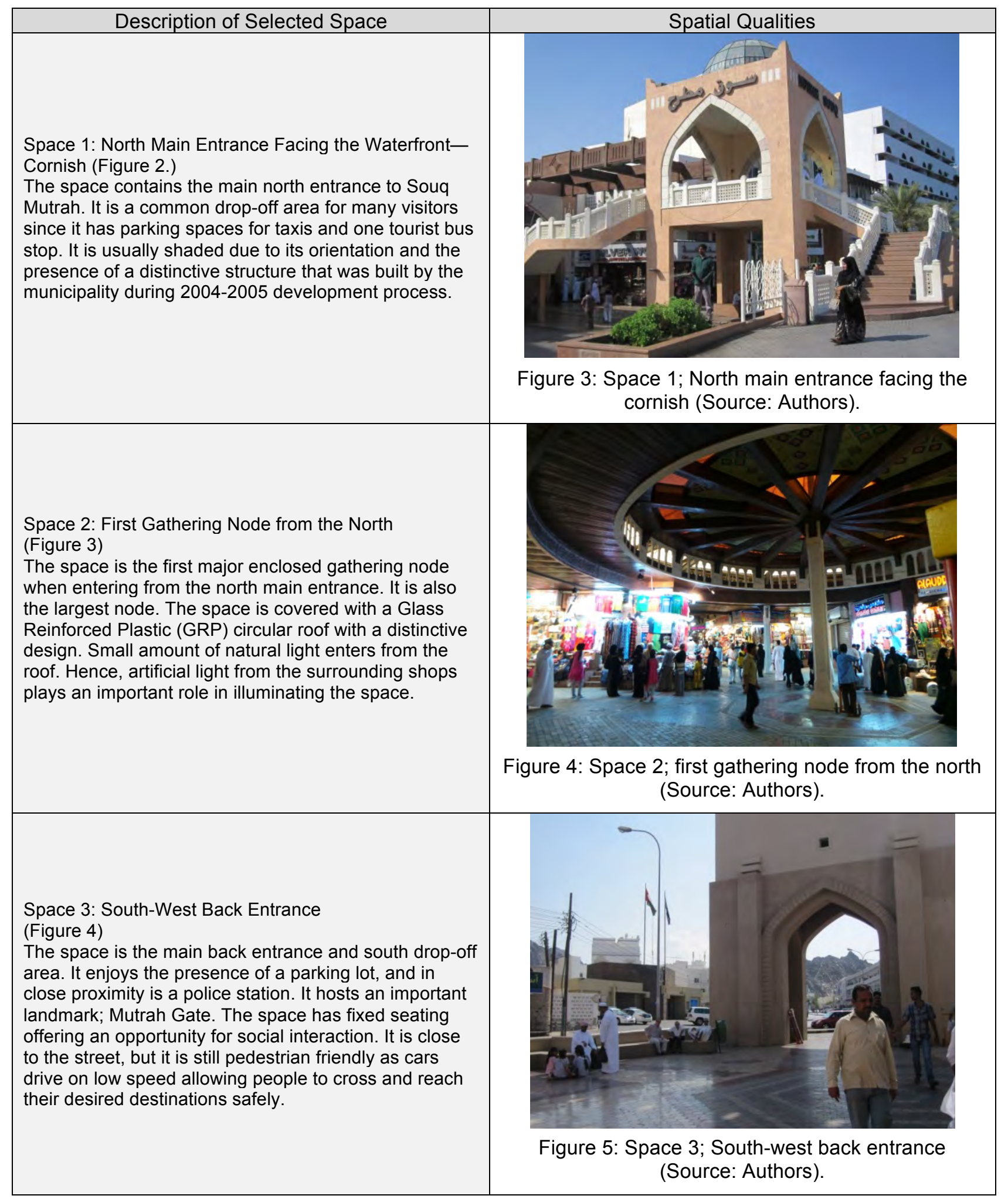




\section{Walk-Through Assessment}

This tool highlights a way to assess urban spaces-market places and their social fabric within Souq Mutrah. In this context, It is important to define the major aspects that reflect the spatial and sociocultural characteristics and the way in which they evolved from the literature. Then, describe how these aspects are translated into an assessment tool and how the walking tour technique should be implemented (Figures 6 and 7).

Description of the tool: An overview of the literature that relates to urban open spaces and shopping places was conducted. Starting with dimensions of urban public spaces, Carmona et al (2003) addressed a number of dimensions that include: morphological, perceptual, social, visual, functional, and temporal. These dimensions are interrelated and influence each other, hence help understand and evaluate urban spaces. The identification and discussion of the key issues underlying these dimensions are comprehensive in nature and relate to the earlier work of Lynch (1960) and Jacob (1961).

Additionally, several similar assessment tools were examined and taken into consideration. The first is a walk-through assessment tool for urban public spaces in Qatar (Salama and Wiedmann, 2013). The tool addressed three major aspects that include functional, social, and perceptual dimensions. It encourages considering; the nature of use, environmental conditions, comfort and relaxation, the social use of space, diversity and social mix, safety and security, environmental meaning and sensory experience, personal space and privacy, territoriality and personalization. The second tool was developed by Salama et al (2008), which involves a method to assess the architecture of shopping malls in Qatar. It encompasses a number of characteristics based on the earlier work of Sanoff (1991) including surrounding context, massing, interface, wayfinding, socio-spatial relationship, and comfort. The examination of these tools concluded in identifying the key issues relevant to the examination of the three spaces within Souq Mutrah.

Operational definitions of factors: A total of six factors have been identified underlying two categories; spatial and socio-cultural characteristics. Recognizing that the spaces under investigation are considered urban spaces in shopping places, the factors combine the characteristics of both. The objective of this procedure is to attempt to translate the concepts involved in the assessment process into some measurable factors. While the weight of each factor varies according to its contribution to the overall quality of the urban space -shopping place- social fabric, they are treated equally in this assessment. Spatial aspects consist of; context, wayfinding, and functionality, while socio-cultural aspects consist of users and interaction, safety and comfort, culture and identity (Table 2).

Procedure: In order to introduce a step-by-step procedure for assessment, this walking tour survey tool is designed to facilitate a deeper understanding of urban spaces, their different attributes and the users associated with them through self-guided tours. The tool is structured in terms of checklists underlying two major groups or sets of aspects (Spatial and Socio-cultural). Notably, each set of aspects involves checklists with a scoring system and is structured in a manner that allows the person performing the assessment to take a structured walk-through in an urban open space. The evaluation strategy in this sense is considered to be impressionistic which increases the understanding of the physical environment and the social experience involved by focusing on specific factors. Checklists are phrased in the form of questions underlying each set of aspects. Questions are designed in a generic manner that reflects the essence and the issues of concern. Numerical scores are assigned to the questions to represent the degree of appropriateness using a four-point scale. Scores are averaged and an overall score for each urban space is then calculated. In sum, the procedure includes the following steps:

1. Conducting a self-guided tour, starting with the surrounding context, then the major points of access to the spaces, then the space itself.

2. Numerical scores from 1 to 4 are assigned to each question underlying the set of aspects (1=Highly Inappropriate, 4=Highly Appropriate). 
3. Responding to each question and adding related notes.

4. Analyzing the numerical ratings by computation of average scores for each factor, then computation for the overall scores of the space.

5. Comparing the scores of the spaces.

6. Developing concluding comments and introducing supporting illustrations, while highlighting positive and negative aspects.

Table 2: Operational definitions of the factors included in the walk-though assessment tool

(Source: Authors, 2013).

\begin{tabular}{|l|l|l|}
\hline Aspects & Factors & Operational Definition \\
\hline \multirow{4}{*}{ Spatial } & Wontext & $\begin{array}{l}\text { Addresses pattern of surrounding streets, scale, } \\
\text { character of the area, public-private relationship, } \\
\text { connectivity, and land use. }\end{array}$ \\
\cline { 2 - 3 } & Fayfinding & $\begin{array}{l}\text { Addresses linkage to surroundings, moving modes, } \\
\text { pathways legibility, and flows of traffic and people. }\end{array}$ \\
\cline { 2 - 3 } & Functionality & $\begin{array}{l}\text { Addresses level of interest in space, role of physical } \\
\text { environment and atmosphere in achieving the space } \\
\text { objectives, level of attracting tourists, businesses, and } \\
\text { regular visitors. It also addresses the level in which } \\
\text { the space is memorable, and its position as a major } \\
\text { attraction in the neighborhood and the city. }\end{array}$ \\
\hline \multirow{5}{*}{$\begin{array}{l}\text { Socio- } \\
\text { cultural }\end{array}$} & $\begin{array}{l}\text { Users } \\
\text { Safety and } \\
\text { Comfort }\end{array}$ & $\begin{array}{l}\text { Addresses accessibility and equitability for all potential } \\
\text { users, encouragement of interaction among them, } \\
\text { diversity of social activities in the same time and in } \\
\text { different times (temporal dimension) and level of } \\
\text { personalization. }\end{array}$ \\
\cline { 2 - 3 } & $\begin{array}{l}\text { Addresses boundaries, security personnel, security } \\
\text { cameras, thermal comfort, noise level, lighting level, } \\
\text { privacy and personal space. }\end{array}$ \\
\cline { 2 - 3 } & $\begin{array}{l}\text { Culture and } \\
\text { Identity }\end{array}$ & $\begin{array}{l}\text { Addresses; the role of users, activities, space } \\
\text { atmosphere/ambiance, representation of the cultural } \\
\text { identity of the country, meaning, important events, and } \\
\text { place attachment. }\end{array}$ \\
\hline
\end{tabular}




\section{Spatial Aspects}

\begin{tabular}{|c|c|c|c|c|c|}
\hline $\begin{array}{c}\text { Context } \\
\text { Highly Inappropriate } 1234 \text { Highly Appropriate } \\
\end{array}$ & Score & $\begin{array}{l}\text { Wayfinding } \\
\text { Highly Inappropriate } 1234 \quad \text { Highly Appropriate }\end{array}$ & Score & $\begin{array}{l}\text { Functionality } \\
\text { Highly Inappropriate } 1234 \text { Highly Appropriate }\end{array}$ & Score \\
\hline $\begin{array}{l}\text { 1- How does this space suit the pattern of the } \\
\text { surrounding streets? }\end{array}$ & & $\begin{array}{l}\text { 1- Are sufficient routes, pathways, streets and } \\
\text { passageways provided to and around this space? }\end{array}$ & & $\begin{array}{l}\text { 1- To what degree could the spatial experience in } \\
\text { this space be described as being interesting? }\end{array}$ & \\
\hline $\begin{array}{l}\text { 2- How does the scale of this space suit the site it sits } \\
\text { upon? }\end{array}$ & & $\begin{array}{l}\text { 2- How effectively do the routes link this space to the } \\
\text { surrounding spaces or buildings? }\end{array}$ & & $\begin{array}{l}\text { 2- How well does the physical layout of space } \\
\text { serves in indicating and achieving its objective? }\end{array}$ & \\
\hline $\begin{array}{l}\text { 3- How does the scale of this space suit the scale of } \\
\text { the surrounding buildings and spaces? }\end{array}$ & & $\begin{array}{l}\text { 3- To what degree do routes support different types of } \\
\text { moving modes (walking, cycling)? }\end{array}$ & & $\begin{array}{l}\text { 3- How well does the general atmosphere of space } \\
\text { serves in indicating and achieving its objective? }\end{array}$ & \\
\hline $\begin{array}{l}\text { 4- How does the scale of this space suit the character } \\
\text { of the neighborhood? }\end{array}$ & & $\begin{array}{l}\text { 4- How well are the circulation routes marked? Are the } \\
\text { markings clear and easily understood? How efficient is } \\
\text { the signage system? }\end{array}$ & & $\begin{array}{l}\text { 4-To what degree is the space approached as a } \\
\text { shopping destination? }\end{array}$ & \\
\hline $\begin{array}{l}\text { 5- Does the appearance of this space fit well with } \\
\text { character of the neighborhood? }\end{array}$ & & $\begin{array}{l}\text { 5- Are all the circulation routes to the space marked or } \\
\text { easily understood? Would a visitor know where to go on } \\
\text { entering the space? }\end{array}$ & & $\begin{array}{l}\text { 5-To what degree is the space approached as a } \\
\text { touristic destination? }\end{array}$ & \\
\hline $\begin{array}{l}\text { 6- To what degree is the public-private relationship } \\
\text { clear in the space? }\end{array}$ & & $\begin{array}{l}\text { 6- What are the flow patterns of traffic or people? Are } \\
\text { there busy periods, quiet periods, one-way flows, regular } \\
\text { movement patterns, traffic jams? Are the routes } \\
\text { arranged to consider these factors? }\end{array}$ & & $\begin{array}{l}\text { 6- To what degree does the space attract } \\
\text { businesses within/ surrounding? }\end{array}$ & \\
\hline $\begin{array}{l}\text { 7- To what degree is this space well-connected to the } \\
\text { surrounding buildings and spaces? }\end{array}$ & & & & $\begin{array}{l}\text { 7- To what degree is the architectural character of } \\
\text { this space being memorable? }\end{array}$ & - \\
\hline $\begin{array}{l}\text { 8- Does the use of this space fit harmoniously with } \\
\text { the adjacent uses? }\end{array}$ & - & & & $\begin{array}{l}\text { 8- To what degree could this place be described as } \\
\text { a major attraction in the neighborhood and the } \\
\text { city? }\end{array}$ & - \\
\hline Average Score (total scores/8) & 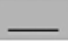 & Average Score (total scores/6) & & Average Score (total scores/8) & - \\
\hline Notes: & & Notes: & & Notes & \\
\hline
\end{tabular}

Figure 6. Spatial aspects included in the walk-through assessment procedure (Source: Authors).

\section{Socio-Cultural Aspects}

\begin{tabular}{|c|c|c|c|c|c|}
\hline $\begin{array}{l}\text { Users and Interaction } \\
\text { Highly Inoppropriate } 1234 \quad \text { Highly Appropriate }\end{array}$ & Score & $\begin{array}{l}\text { Safety and Comfort } \\
\text { Highly Inappropriate } 1234 \text { Highly Appropriate }\end{array}$ & Score & $\begin{array}{l}\text { Culture and Identity } \\
\text { Highly Inappropriate } 1234 \quad \text { Highly Appropriate }\end{array}$ & Score \\
\hline $\begin{array}{l}\text { 1-To what degree does the space promote human } \\
\text { direct experience while supporting the activities of and } \\
\text { interaction among people? }\end{array}$ & & $\begin{array}{l}\text { 1- To what degree does the space foster the feeling } \\
\text { of comfort and relaxation? }\end{array}$ & & $\begin{array}{l}\text { 1- To what degree do the users of space represent the } \\
\text { cultural identity of the country? }\end{array}$ & \\
\hline $\begin{array}{l}\text { 2- To what degree could this space be described as } \\
\text { being socially inclusive? }\end{array}$ & & $\begin{array}{l}\text { 2- To what degree does the space consider the } \\
\text { dimensions of personal space and privacy? }\end{array}$ & & $\begin{array}{l}\text { 2- To what degree does the activities in this space } \\
\text { represent the cultural identity of the country? }\end{array}$ & \\
\hline $\begin{array}{l}\text { 3- To what degree does the space encourage the use of } \\
\text { several social groups? } \\
\text { Age } \\
\text { Cultural/Ethnic Background } \\
\text { Gender }\end{array}$ & & $\begin{array}{l}\text { 3- To what degree does the space offer the feeling } \\
\text { of safety and security to its users? } \\
\text { Boundaries } \\
\text { Security Personnel } \\
\text { Security Cameras } \\
\text { Exits }\end{array}$ & & $\begin{array}{l}\text { 3- To what degree does the general atmosphere } \\
\text { (including textures, colors, odors, noise, natural } \\
\text { elements) of this space reflect the identity of the } \\
\text { country? }\end{array}$ & \\
\hline $\begin{array}{l}\text { 4- To what degree does this space accommodate } \\
\text { diverse social activities? And to what degree do } \\
\text { activities change with time (Example; morning/ night)? }\end{array}$ & & $\begin{array}{l}\text { 4- How does the space suit an individual's thermal } \\
\text { comfort? }\end{array}$ & & $\begin{array}{l}\text { 4- To what degree does the architectural character of } \\
\text { this space reflect the identity of the country? }\end{array}$ & \\
\hline $\begin{array}{l}\text { 5- To what extent does this space promote interaction } \\
\text { between different social groups? } \\
\qquad \text { Cultural/Ethnic Background } \\
\text { Gender }\end{array}$ & & $\begin{array}{l}\text { 5- How suitable is the ability to adjust thermal } \\
\text { comfort on an individual basis? }\end{array}$ & & $\begin{array}{l}\text { 5. To what degree does this space re-produces a } \\
\text { memory of the past, meaning, symbolisim, and } \\
\text { events that may have happened? }\end{array}$ & \\
\hline $\begin{array}{l}\text { 6- To what extent do the uses in this space serve } \\
\text { different social groups? } \\
\text { Landscape Elements }\end{array}$ & & $\begin{array}{l}\text { 6- How appropriate is the light level in the space } \\
\text { during the day? }\end{array}$ & & $\begin{array}{l}\text { 6- To what degree does the space create an } \\
\text { attachment to the spirit of place? }\end{array}$ & 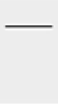 \\
\hline $\begin{array}{l}\text { 7- To what extent is this space accessible to diverse } \\
\text { social groups? } \\
\text { Location } \\
\text { Transportation Options }\end{array}$ & & $\begin{array}{l}\text { 7- How appropriate is the light level in the space } \\
\text { during the night? }\end{array}$ & & & \\
\hline $\begin{array}{l}\text { 8- How well does the space suit the user's ability to } \\
\text { personalize their part of space? }\end{array}$ & & $\begin{array}{l}\text { 8- How appropriate is the perceived noise level in } \\
\text { the space? }\end{array}$ & 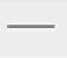 & & \\
\hline Average Score (total scores/14) & & Average Score (total scores/11) & & Average Score (total scores/6) & \\
\hline Notes: & & Notes: & & Notes & \\
\hline
\end{tabular}

Figure 7. Socio-cultural aspects included in the walk-through assessment procedure (Source: Authors). 


\section{Behavioral Mapping}

Behavioral mapping is used to systematically document location-based observations of human activity in a space, using annotated maps, plans, video, or time-lapse photography. They are used to document readily observable characteristics, movements, and activities, including approximate ages and genders, whether people are alone or with others, what they are doing, time spent at fixed location or in transit, and the details of the environmental context (Hanington \& Martin, 2012).

It is a direct approach and a mechanism for understanding the dynamics of people and their interaction with the urban environment; it is an alternative approach to data collecting that views people as 'objects' by recording their periodic behavior. Valuable information can be obtained when behavior is systematically recorded (Sanoff,1991). Unplanned observation may result in inadequate findings that may reveal only what seems to be already obvious. Systematic observation of behavior involves four aspects: these are people, activities, setting or space, and timing. There are two types of behavioral maps; place-centered maps that help reveal how or when a particular space is being used or not used (UC-Davis), and individual-centered maps that help reveal the activities of a particular group of individuals throughout a specific period of time (Salama \& Wiedmann, 2013).

Procedure In this study a combined unobtrusive mapping technique, which integrates 'placecentered' and 'individual-centered' mapping, is used. This survey tool is designed to enable a profound understanding of the dynamics of these urban spaces, type of users and their behavior noting that they will be produced based on a scheduled observation plan. It includes observations in the mornings and evenings in weekdays and weekends. The results are envisioned in a representative map of movement, behavior and activities of users for each space. The summary of procedures can be outlined as follows:

1. Produce a simple map that illustrates the ground level of the space, its boundaries, plantations, and surrounding roads and parking.

2. Generate a schedule of observation, noting that the space will be observed four times producing four maps, each for an observation period: weekday morning, weekday evening, weekend morning, and weekend evening.

3. Maps illustrate gender; age group, and socio-economic background.

4. Each time of observation will be for 30 minutes, noting that it also includes writing comments of significant actions in space.

5. Using the four maps to produce two cumulative maps for weekday and weekend.

6. Using the weekday map and the weekend map to produce a map that represents the overall profile of users behavior in space.

7. Develop concluding comments and introducing supportive illustrations, while highlighting positive and negative aspects.

\section{COMPARATIVE ANALYSIS AND INTERPRETATION OF THE RESULTS}

\section{Walk-through Assessment}

Conducting the walk-through assessment reveals various degrees of appropriateness. The table below illustrates the results of assessing the three spaces. It offers a preliminary level of comparison between the spaces while developing a better understanding of Souq Mutrah spatial and socio-cultural aspects. Space 1 and space 2 received equal average score, which was higher than that of space 3 (Table 3 and Figure 8 ). 
Table 3: Results of all three spaces (Source: Authors).

\begin{tabular}{|c|c|c|c|c|}
\hline Aspect & Factor & Space 1 & Space 2 & Space 3 \\
\hline Spatial & Context & 3.34 & 3.56 & 2.97 \\
\cline { 2 - 5 } Aspects & Wayfinding & 2.83 & 2.42 & 2.63 \\
\cline { 2 - 5 } & Functionality & 3.31 & 3.44 & 3.25 \\
\cline { 2 - 5 } & Average & 3.16 & 3.14 & 2.95 \\
\hline Socio- & Users and Interaction & 2.73 & 2.64 & 3.00 \\
\cline { 2 - 5 } Cultural & Safety and Comfort & 2.32 & 2.32 & 1.91 \\
\cline { 2 - 5 } Aspects & Culture and Identity & 3.21 & 3.42 & 3.38 \\
\cline { 2 - 5 } & Average & 2.75 & 2.79 & 2.76 \\
\hline & Average Score & 2.96 & 2.96 & 2.86 \\
\hline \multicolumn{2}{|r|}{} & & \\
\hline
\end{tabular}

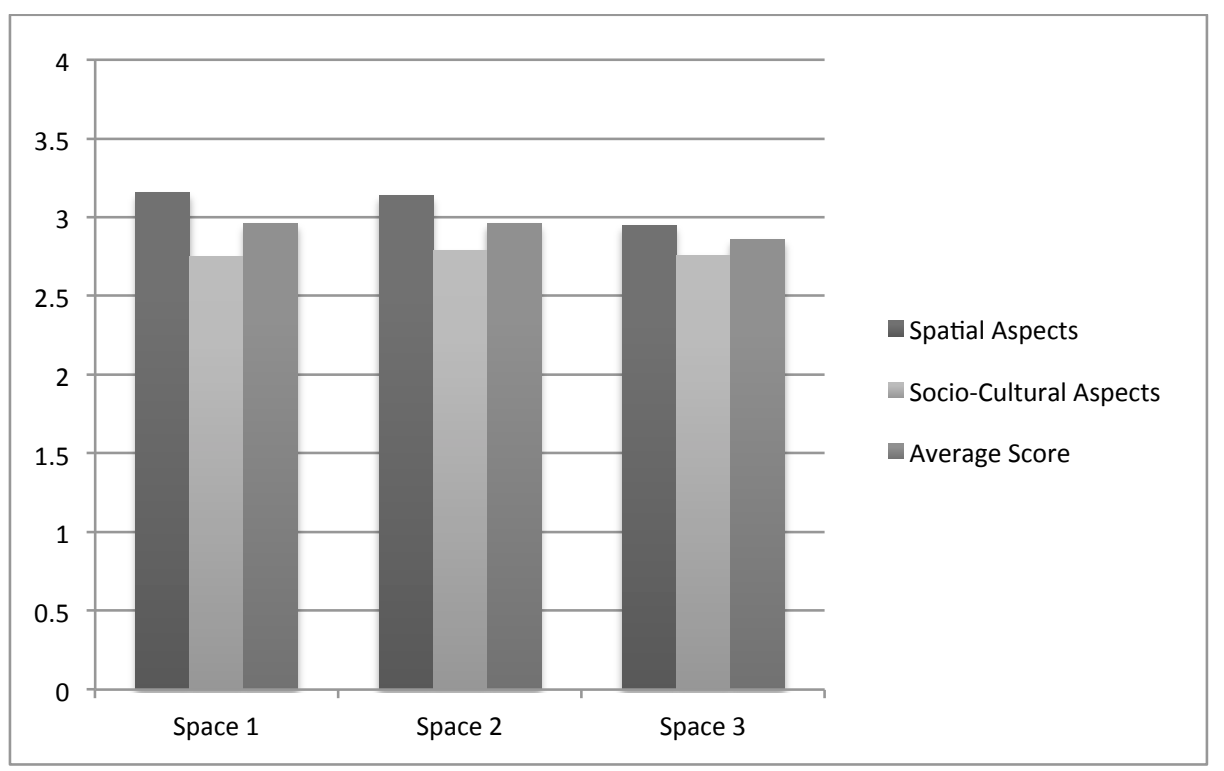

Figure 8: Average scores resulting from assessing the three spaces (Source: Authors).

\section{Spatial Aspects}

Context: Space 2 received the highest score while space 3 received the lowest in context. Space 2 is created by the meeting of five pathways in one node. Thus, it matches the site it sits upon in terms of scale and offers a unique character with its decorative ceiling. It is very well connected comparing to the other two spaces. The public and private relationship is notable by the clearly identified pathways. It also fits the surrounding uses. Whereas Space 3 is somewhat poor in scale in relation to the site it sits upon and the surrounding buildings and gate structure. It is very crowded with people and vehicles, but still maintains a clear private and public relationship. It is a back entrance for the souq used by many residents of Mutrah areas.

Wayfinding: Space 1 obtained the highest score while space 2 received the lowest in wayfinding. Space 1 has wide pathways with good connection that allows the use of different modes of movement. It has a very visible large sign indicating the entrance of the souq. People move through freely and in a faster pace than inside the souq. However, in space 2 only two of the five pathways allow good movement and pedestrian flow. Walking is the most convenient movement mode. Notably, there are no directional signs for all the five pathways making it very difficult for visitors to reach their desired destinations.

Functionality: Space 2 has the highest score while space 3 received the lowest in functionality. On the one hand, Space 2 is located inside of the souq and maintains more of its original character than the other spaces. It is also the largest meeting node where shops cater to diverse populations 
in terms cultural and socio-economic background. It attracts visitors; locals and foreign tourists to pass by, stop to shop or decide where to go next, stand and wait for someone, or just take small break to enjoy shop fronts. On the other hand, space 3 is located on the back of the souq making it less interesting or used by the tourists as notable from the observations. It is certainly more used by residents of the neighborhoods of Mutrah. It is approached to take a walk, sit and relax, or simply cycle through. Seats are packed at night but not in the morning due to the extreme heat absorbed by the marble seats without shading devices. Yet, it remains notable due to the presence of Mutrah Gate.

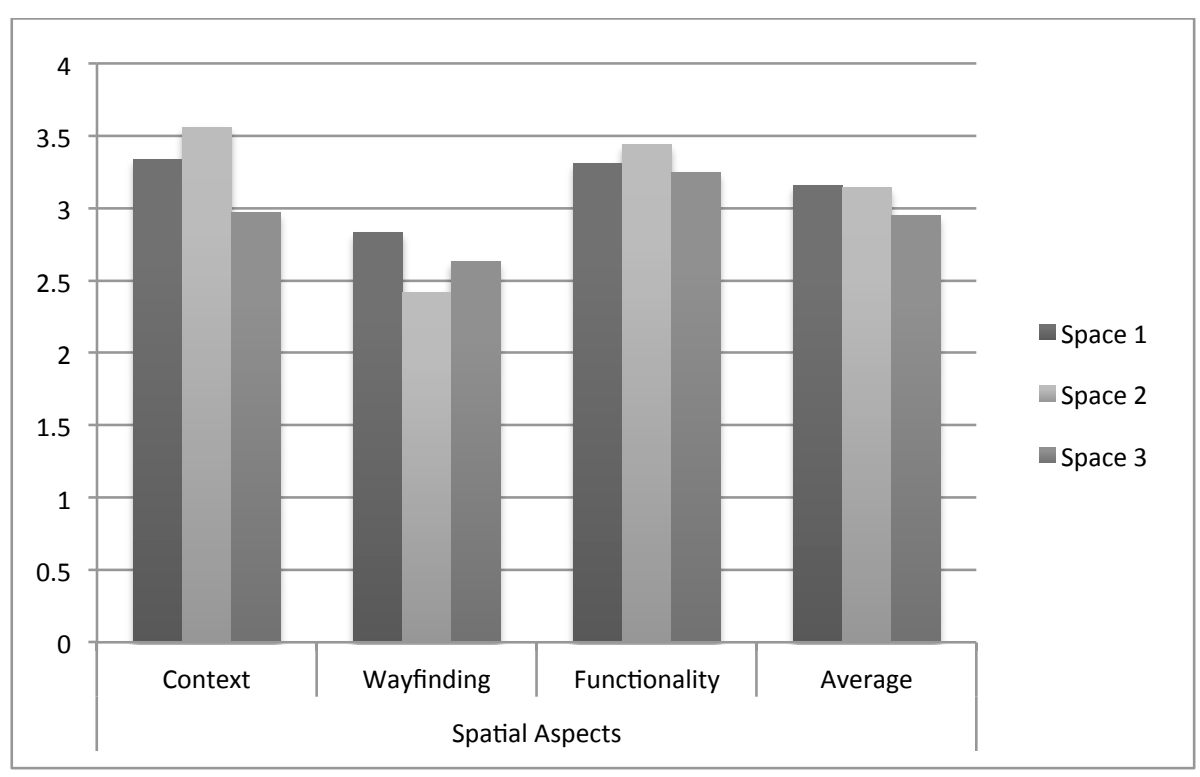

Figure 9: Average scores of resulting from assessing the spatial aspects of the three spaces (Source: Authors).

\section{Socio-cultural Aspects}

Users and Interaction: Space 3 received the highest score while space 2 obtained the lowest in users and interaction. Space 3 can be described as socially inclusive. It encourages the use of different age groups, people from different cultural/ ethnic backgrounds, and both genders. Users come to shop, sit, relax, socialize, wait for someone to meet or pick them up, ride their bikes, or explore the place. Interaction is encouraged by the dimensions of space, built seats and visibility. It is accessible by different transportation means. Except for shopkeepers, most users have minor ability to personalize their part of space. However, space 2 uses are limited to shopping. People move in a relatively fast pace crossing through the space which minimizes the level of interaction. The space is accessible by walking or cycling with little opportunity for personalization.

Safety and Comfort: Spaces 1 and 3 received equal scores that are relatively high, leaving space 2 with the lowest score in safety and comfort. Notably, this factor appears to be the lowest when compared with other factors. Consequently, the major positive feature in space 1 is the boundaries and exits that create a sense of safety and security. Also, the shade under the structure at the entrance allows for more comfort. Additionally, lighting at night is suitable and enriches the spirit of the space. On the other hand, in space 3 the built seats somewhat create a physical barrier from the street, which supports safety. Also, the openness of the space and proximity to the police station on its south-east side create a sense of safety and security. As well, lighting at night is suitable allowing good visibility. Space 2 on the other hand, has a low presence of security personnel in the absence of security cameras. The fully covered ceiling allows minimum natural lighting and high dependency on artificial lighting of the shop fronts. 
Culture and Identity: With very close results, space 2 got the heist score while space 1 got the lowest score in culture and identity. The users, activities, architectural design and general atmosphere of space 2 represent the cultural identity of the country. Attachment to space is created by the general atmosphere of the space and the loyal customers that come again and again. Moving to space 1, there is a mix of architectural styles that may not be harmonized like space 2. But it still creates an attachment to it by the magnificent view to the Cornish, port, beautiful ships and traditional boats.

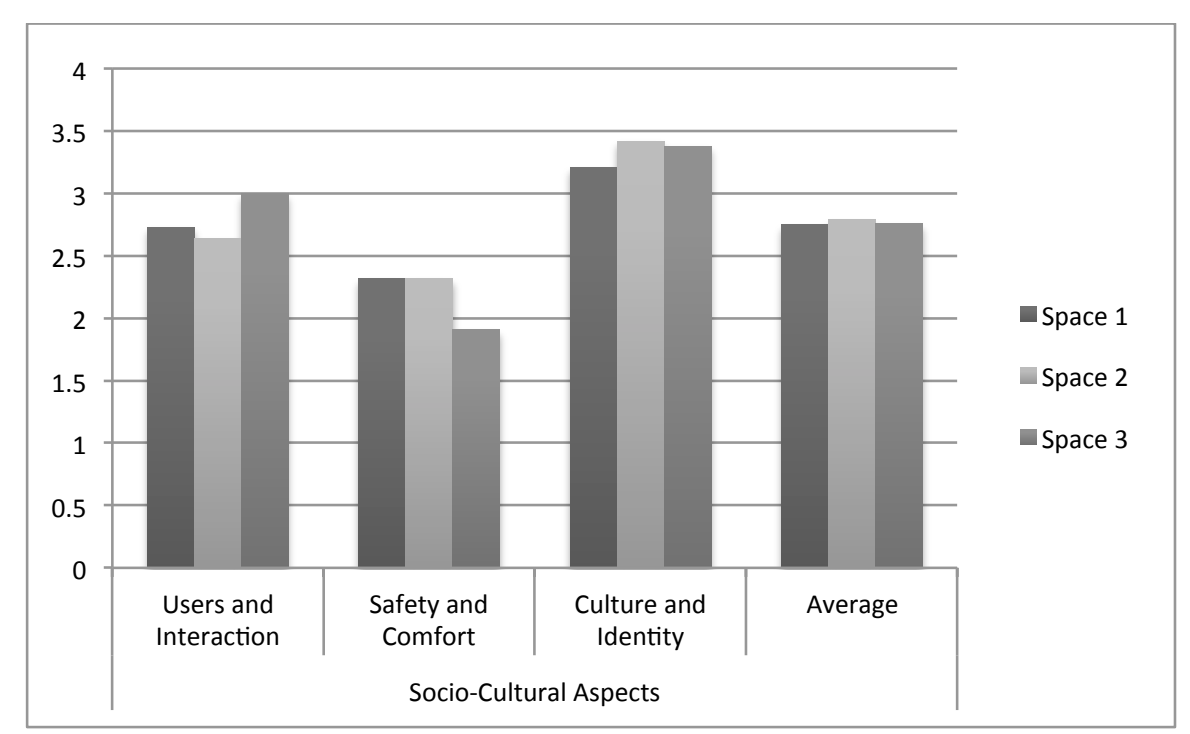

Figure 10: Average scores of resulting from assessing the socio-cultural aspects of the three spaces (Source: Authors).

\section{Behavioral Mapping}

The 30-minute observation periods undertaken in the three spaces in weekday morning, weekday evening, weekend morning and weekend evening, reveal variations in the number and direction in which people move and spatially interact with space. Cumulative average maps were developed to establish an overall profile for each space (Figures 11, 12, 13).

Users: While diverse population are present in the three spaces in terms o gender and age groups, space 2 appears to have more adults than children. In terms of ethnic backgrounds they are various with a notable density of Omanis, Indians, Pakistanis, and tourists from but not limited to European and Gulf countries. However, space 3 appears to have a fewer tourists yet it has a notable density of Omani old males who visit to sit, relax, and socialize. In space 1 young and old Omani male visitors have certain regular spots in which they sit and socialize. Space 3 has regular three Omani old males who sell snacks in certain spots. In space 1 and 2, there are more numbers of bicycle riders who are male and female teenagers, in addition to some male expatriate laborers. It is noted that laborers in the three spaces are limited to males who are cart pushers, cleaners, shopkeepers, and cafeterias food servants.

Time of use: Cleaners work all day long since the spaces are crowded in mornings and evening, in weekdays and weekends. However, mornings are more suitable for floor cleaning since other times are usually very crowded and users may be disturbed or find difficulty to move. All the spaces are least crowded in weekday mornings and most crowded in weekend evenings. Also, there are more tourists in the evening times. This may be due to different reasons; first; morning working hours of visitors; second, high temperatures especially in summer time; third, shops opening hours. As in regular weekdays shops open from 9:00 or 10:00 AM then closes at 1:00 PM, opens again at 4:00 PM to 10:00 PM. In Ramadan they open from 9:00 AM close at 1:00 PM, open 
again at 4:00 PM to $1: 00$ or 2:00 AM. Children are more present during the night due to school times. In space 2, there are more single or groups of females in weekday evenings and weekend mornings. Since Space 3 has no shaded areas except under Mutrah Gate and in front of some shops the seats are rarely used. However, evenings witness large amount of people sitting and socializing especially old Omani men.

Activities: Spaces 1 and 3 are entrance areas to the souq. Thus, the main purpose of visiting them is passing by to enter the souq for the purpose of shopping. However, there are also other activities in these spaces. People come to sit, rest, relax and maybe have a snack under the shaded areas away from the heat. In space 3 users also stand in the middle of the space to chat. On the other hand, space 2 is a vibrant area within the souq and is active with more people moving through and or stopping by to shop.

- In space 1, even though there are three cafés; the one on the west of the space is the most attractive. It has no seats unlike the two other cafés but still attracts many users. Certain spots in this space are very attractive for old Omani men to sit and socialize; on the West nearby the stairs, and on the east on the stairs of the portico. Expatriate workers however choose spots, which are higher in level and closer to the street to enjoy the view to the Cornish. Cycling is notably common in this area due to the large space available compared to the narrow souq path. In the mornings, when sea tides visit the space under the entrance structure, some people see it as an obstacle affecting their movement. However, others see it as opportunity to wash away the heat with cool water, or ride their bicycles through, play and splash water on their friends for fun. When this space is dry, children enjoy looking at the sea waves from under the tunnel. In terms of cleaning, in the evenings buckets of dirty water used to clean the souq pathways are thrown to the sea through the tunnel.

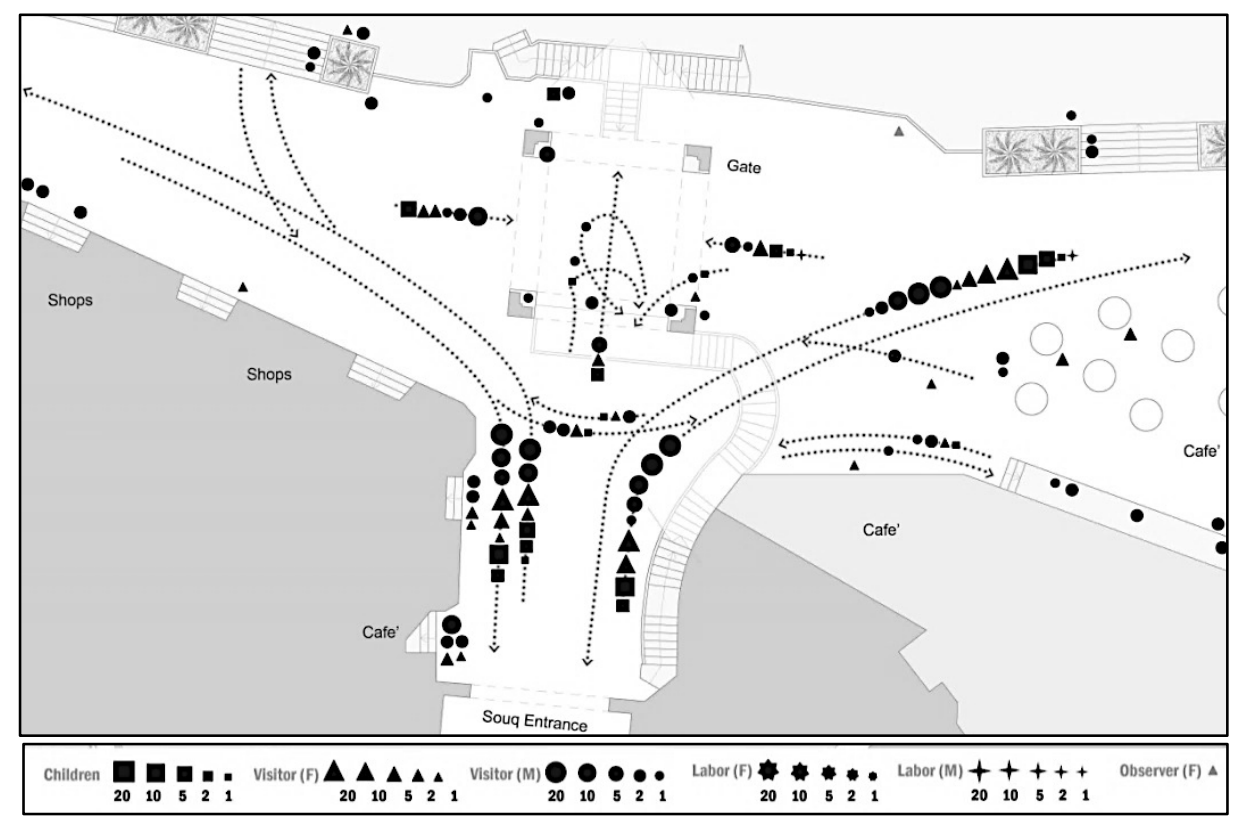

Figure 11. Average behavioral maps of space 1 (Source: Authors).

- Space 2 is one of the major meetings, stopping by, gathering internal shaded nodes or plazas within souq. It connects five pathways. Users pass by it, stop to shop or decide where to go next, stand and wait for someone, or just take small breaks to enjoy the souqs' architecture and decorative designs. Children see it as a place to cycle through slowly or play in, even if just for a few minutes while their parents are shopping. Cart pushers stand looking for costumers or move across with goods for either the businesses in the souq, or for shoppers 
that need help carrying goods. Cleaners pass by regularly to pick up the trash or wash the floors. Shopkeepers and sellers are available during working hours either sitting inside the shops or standing outside welcoming people to their shops. Two shops attract many shoppers; one on the north, and another on the west. Additionally, the space does not provide any seats; hence the stairs of one of the closed shops are used by adult males to rest on while adult females and their children shop.

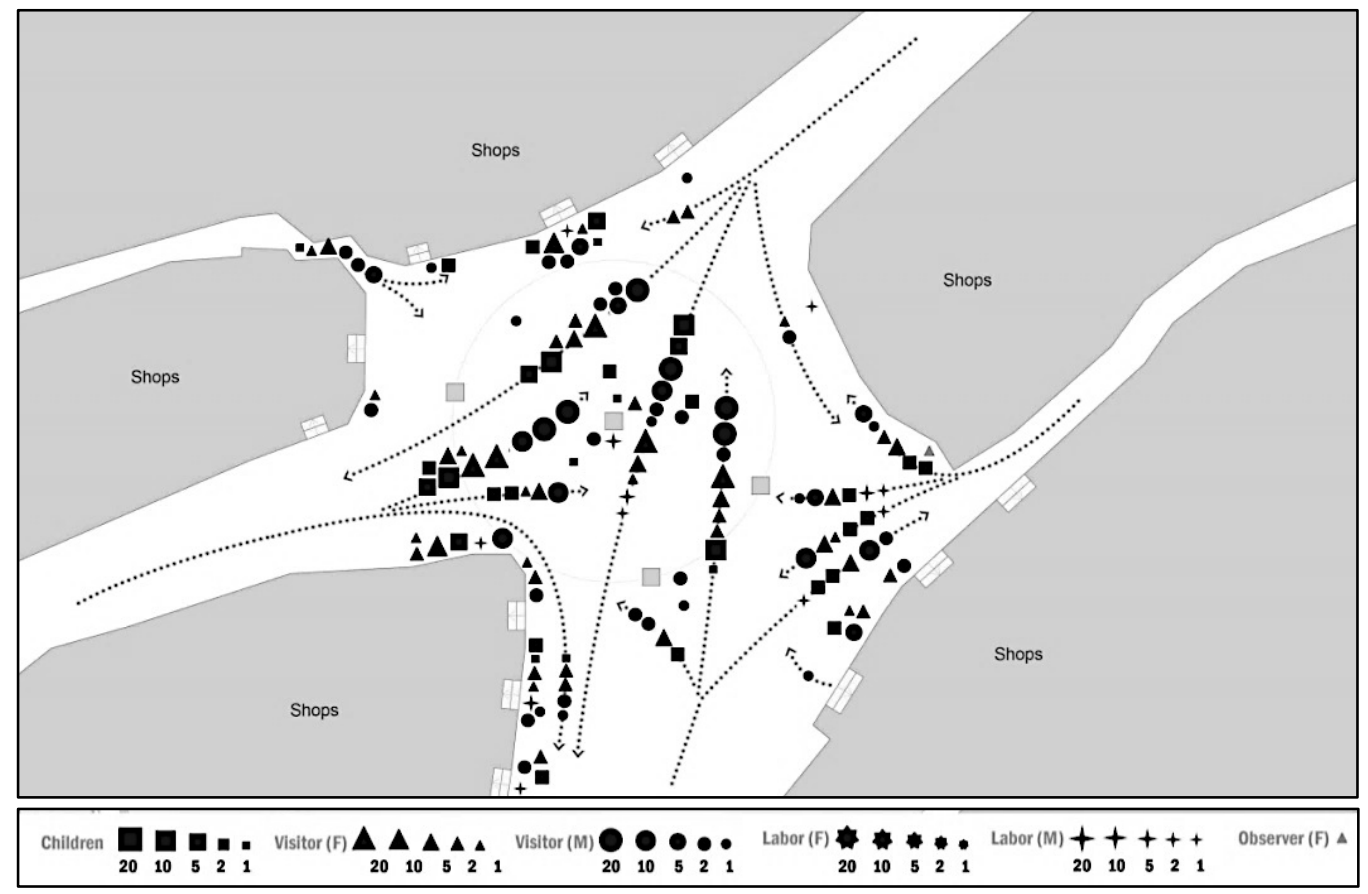

Figure 12. Average behavioral maps of space 2 (Source: Authors).

- Space 3 is within a crowded area of the souq that makes it very difficult to find parking; hence users use this space as a drop off and waiting area for their rides. The seats in this space are very attractive for old Omani men to sit and socialize, while very few females or children get their share in these seats. Cart pushers move across with goods for either the businesses in the souq, or for shoppers that need help carrying goods. There are two old Omani men sitting under Mutrah Gate in the day time selling a traditional Omani snack made of cheese called Shelanch, while in the evening they sit beside the gate to be more visible for buyers. Another Omani vendor sells other types of snacks, sitting under the shade of the shops on the west of the entrance. Tourists tend to exit the souq, stand in the space and look around, and then enter back inside to explore other parts of the souq. Cycling is not very common in this space in comparison with the other two spaces. The café attracts many Omanis for a cold refreshing drink or a fast snack under a shaded pathway. 


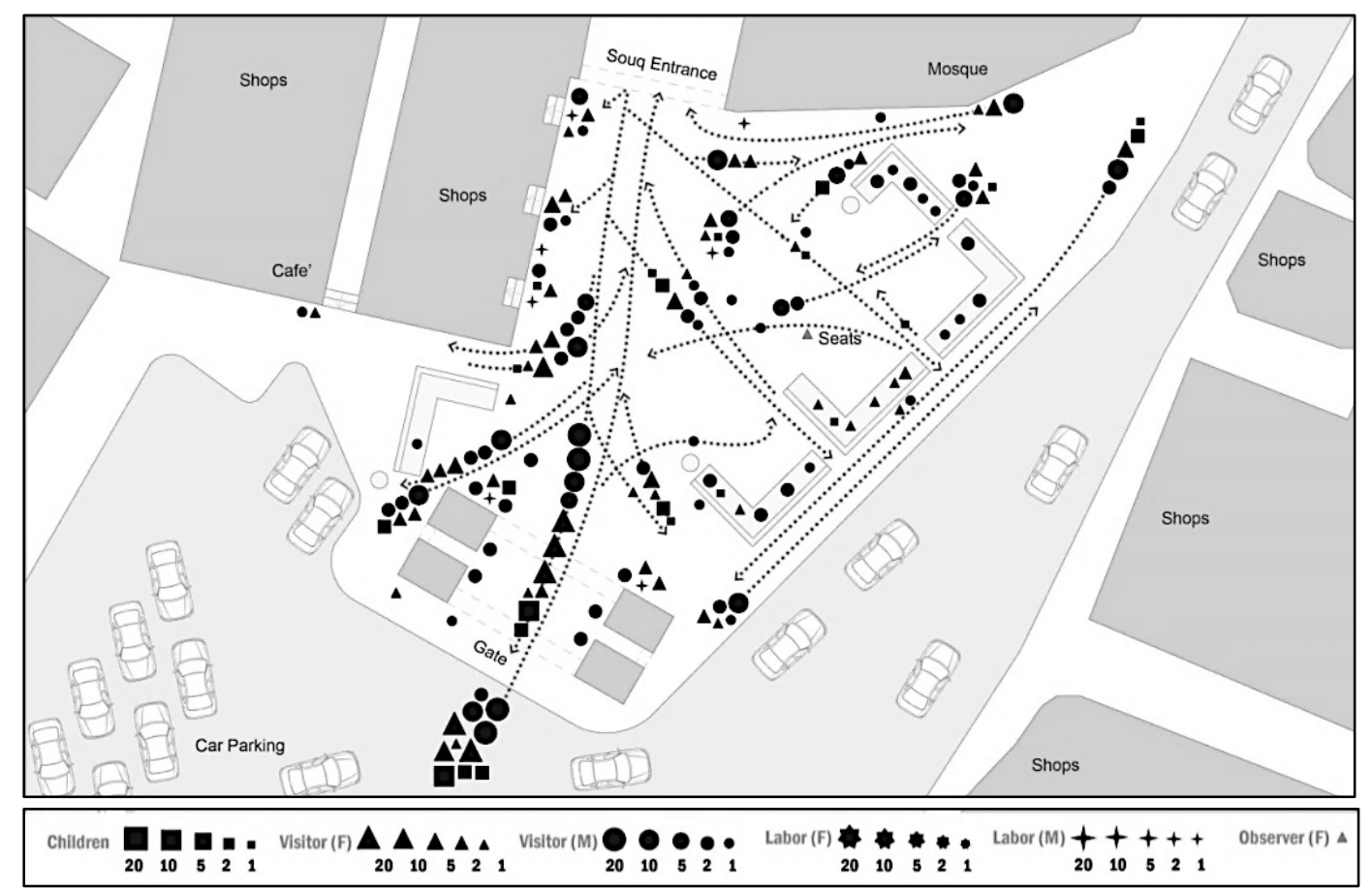

Figure 13. Average behavioral maps of space 3 (Source: Authors).

\section{CONCLUSION}

Both spatial aspects and socio-cultural aspects are interrelated relating space and people together in a reciprocal manner. The examination of the spatial aspects the three spaces of Souq Mutrah demonstrates certain characteristics. While the factors of functionality and context appear to support people needs, the wayfinding factor seems to be poor in the absence of a signage system or demarcated spaces or in the lack distinctive qualities of those spaces. The spatial environment matches the context and relates successfully to the creation of an intimate scale. It also considers the visibility of activities from long distances. The spaces are attracting locals and expats from both genders, while workers are mostly males. Expats visit the souq as a touristic destination while locals from the surrounding neighborhoods visit it for various purposes including work. The spaces can be described as memorable due to dramatic lighting as in the case of space 1, the decorative elements and the display of goods as the in space 2, and the presence of Mutrah gate as in the case of space 3 .

The examination of the socio-cultural aspects reveals that the three spaces have unique identity and are representative of the local culture allowing for effective users interaction; however they face significant issues in terms of safety and security. There is a low presence of security personnel and security cameras in all the spaces. They are also hard to control in terms of thermal attributes. Lighting is suitable, but is also much lower than in contemporary shopping malls. Each space presents part of the culture and history and has its own spirit; as space 1 relates the souq to the sea, fishing, the views and vernacular architecture. Space 2 presents the shopping environment and the way people move and interact in such spaces, while space 3 presents the connection to the surrounding neighborhoods and the daily gatherings of people to sit and socialize. Even though the spaces are relatively socially inclusive and cater for all social groups, there are notable numbers of low and medium income. This is due to the quality of the products and services that do not satisfy high-income locals or expatriates.

The behavioral mapping of the three spaces demonstrates that there are more visitors in the evenings and even more in the weekends. This is due to working hours and also due to harsh climatic conditions during the summer time. The spaces experience regular spots where groups of people gather, sit, socialize, and enjoy their time. Tourists prefer that use of space 1 to enter the 
souq due to the availability of bus stops and taxies. They usually walk slower than regular users for the purpose of exploring the place and experience the culture of the souq. Many of the regular visitors seem to know each other well. There is a sense of community within the three spaces.

While the implementation of walk-through assessment and behavioral mapping procedures reveals key insights into the understanding of the spatial and cultural environment of the souq, other methodological procedures could be implemented in future investigations. In essence, the outcomes of this work offers initial understanding of the role of the souq today, the level of deterioration, the impact of local authorities' efforts, and the impact of new developments in the city including the rising interest in introducing shopping malls. The results also offer some reasoning relevant to the level of impact of urban sprawl in terms of the number of middle-class visitors. Yet, the souq still enjoys a level of attraction from the locals regardless of the current surge in the construction of shopping malls.

Muscat Municipality and other local authorities need to play a more active and effective role in preserving the souq while enhancing its contribution to the city and its urban society. Revitalizing Souq Mutrah can be seen as a promoter for connecting cultural diversity to historical assets. Enhancing the spatial environment may take place through urban heritage conservation effort. Nonetheless, it does not necessarily mean preserving historical assets as physical artifacts but also as a spirit and life. Both spatial and socio-cultural aspects need to be looked at when making decisions about improvements. Buildings, spaces, social interaction and space appropriation are all important aspects for consideration when embarking on future enhancements to the souq environment. Issues that pertain to social sustainability, cultural diversity, and the presence of various ethnic groups need to be considered in future interventions in the souq.

Architects and urban designers are an integral component of this development process. They need to play a key role in encouraging local authorities to look into the essence of the architecture of the souq, its evolution through people actions, and its current realities. Enhancing the spatial qualities in a manner the supports desired social practices in a traditional environment such as that of the souq while invigorating cultural plurality should be seen as an essential element of future discourses and practices related to the development of the souq.

\section{ACKNOWLEDGEMENTS}

This paper is derived from the Master Thesis entitled "SOCIO-SPATIAL STUDY OF TRADITIONAL SOUQS IN THE ARABIAN PENINSULA: THE CASE OF SOUQ MUTRAH, OMAN" by Ahood AIMaimani under supervision of Ashraf M. Salama and Fodil Fadli, submitted to the Department of Architecture and Urban Planning, Qatar University.

\section{REFERENCES}

Carmona, M., Heath, T., Oc, T., and Tiesdell, S. (2003). Public Spaces-Urban Spaces: The dimensions of urban design. Oxford: Architecture Press.

Hanington, B., \& Martin, B. (2012). Universal Methods of Design: 100 Ways to Research Complex Problems, Develop Innovative Ideas, and Design Effective Solutions. Retrieved from Safari Books Online (May 17, 2013): http://my.safaribooksonline.com/book/-/9781592537563/06dot-behavioral-mapping/06_behavioral_mapping

Lynch, K. (1960). The Image of the City. Cambridge, MA: The MIT Press.

Jacob, J. (1961). The Death and Life of Great American Cities. New York, NY: Vintage Books.

Oman Census. (2010). Census Final Results 2010. Retrieved from National Center for Statistics and Information (February 15, 2013): http://www.ncsi.gov.om/NCSI_website/documents/Census_2010.pdf

Salama, A. M. and Wiedmann, F. (2013). Demystifying Doha: On Architecture and Urbanism in and Emerging City. Farnham: Ashgate. 


\section{ArchNet}

Salama, A. M. and Wiedmann, F. (2013). The Production of Urban Qualities in the Emerging City of Doha: Urban Space Diversity as a Case for Investigating the 'Lived Space.' Archnet-IJAR: International Journal of Architectural Research, 7 (2): 160-172.

Salama, A. M., Khalfani, F. and Al-Maimani, A. (2013). Experiential Assessment of Urban Open Spaces in Doha. Open House International, 38 (4): 47-57.

Salama, A. M., Al-Nesf, B. E., Hasson, R. A., \& Al Ramahi, H. R. (2008). Learning from Experience: Evaluating Sustainable and Spatial Characteristics of the Architecture of Shopping Malls in Qatar. Qatar National Research Fund, Undergraduate Research Experience Program, 3rd Cycle, Doha.

Sanoff, H. (J1991). Visual Research Methods in Design. New York, NY: Van Nostrand Reinhold.

UCDavis. (n.d.). Behavioral maps . Retrieved from UCDavis (May 17, 2013):

http://psychology.ucdavis.edu/sommerb/sommerdemo/mapping/behmap.htm

\section{Authors:}

\section{Ahood Al-Maimani}

MUPD Post Graduate Student, Department of Architecture and Urban Planning, Qatar University ahood.a.almaimani@gmail.com

\section{Ashraf M. Salama}

Professor of Architecture,

Department of Architecture and Urban Planning,

Qatar University

asalama@qu.edu.qa

\section{Fodil Fadli}

Assistant Professor of Architecture,

Department of Architecture and Urban Planning,

Qatar University

f.fadli@qu.edu.qa 